\title{
Microplastic contamination in market bivalve Argopecten purpuratus from Lima, Peru
}

\author{
Contaminación con microplásticos en el bivalvo comercial Argopecten \\ purpuratus de Lima, Perú
}

Gabriel Enrique De-la-Torre* (iD); Lisseth Meliza Mendoza-Castilla; Rosa Pilar Laura

\begin{abstract}
Microplastics $(<5 \mathrm{~mm})$ are ubiquitous contaminants in the marine environment. Many marine commercial species, among fish, mollusks and crustaceans, are subject to microplastic exposure through ingestion. The aims of the present study were to determine microplastic contamination in scallops from fishery markets of Lima and if microplastics are more likely to adhere to certain parts of the scallop. Argopecten purpuratus specimens were bought from fishery markets in Lima. Soft tissues were digested using $10 \% \mathrm{KOH}$ and incubated at $60{ }^{\circ} \mathrm{C}$ overnight. An optical microscope was used to observe microplastics after vacuum filtration of the supernatant solution. Microplastic concentration, color and type were recorded. ATR-FTIR analysis determined the specific polymer types. The overall mean microplastic concentration was $2.25 \pm$ 0.54 MP.ind $^{-1}$. Fibers were the most abundant microplastic type, while red and blue were dominant colors. Mann Whitney $U$ test indicated no significant differences $(P>0.05)$ of microplastic content between gonads and muscle. Microplastics in seafood and foodstuff could pose a threat to food security and human health. Still, information regarding microplastic pollution is scarce.
\end{abstract}

Keywords: Microplastic; Argopecten purpuratus; contamination; Peru; scallop.

\section{Resumen}

Los microplásticos ( $<5 \mathrm{~mm}$ ) son contaminantes ubicuos en el medio marino. Muchas especies marinas comerciales, entre peces, moluscos y crustáceos, están sujetas a la exposición a microplásticos por ingestión. Los objetivos del presente estudio fueron determinar la contaminación por microplásticos en las vieiras de los mercados pesqueros de Lima y si es más probable que los microplásticos se adhieran a ciertas partes de la vieira. Muestras de Argopecten purpuratus se compraron en mercados pesqueros de Lima. Los tejidos blandos se digirieron usando $10 \% \mathrm{KOH}$ y se incubaron a $60{ }^{\circ} \mathrm{C}$ durante la noche. Se usó un microscopio óptico para observar microplásticos posterior a la filtración al vacío de la solución sobrenadante. Se registró la concentración de microplásticos, color y tipo. El análisis ATR-FTIR determinó los polímeros específicos. La concentración de microplásticos media fue 2,25 \pm 0,54 MP.ind ${ }^{-1}$. Las fibras fueron el tipo de microplástico más abundante, mientras que el rojo y el azul fueron los colores dominantes. La prueba U de Mann Whitney no indicó diferencias significativas $(P>0,05)$ del contenido microplástico entre las gónadas y el músculo. Los microplásticos en los mariscos podrían representar una amenaza para la seguridad alimentaria y la salud humana. Sin embargo, la información sobre la contaminación con microplásticos es escasa.

Palabras clave: Microplásticos; Argopecten purpuratus; contaminación; Perú; vieira.

Universidad San Ignacio de Loyola, Lima, Perú.

*Corresponding author: Gabriel.e.dltp@gmail.com (G.E. De-la-Torre).

G.E. de.la.Torre (D) https://orcid.org/0000-0002-0268-2784

Recibido: 17-06-2019.

Aceptado: 20-08-2019.

DOI: 10.17268/manglar.2019.012 


\section{Introduction}

Microplastics are plastic fragments smaller than $5 \mathrm{~mm}$ in diameter (Andrady, 2017). They are classified as primary or secondary. While primary microplastic are manufactured (e.g. preproduction pellets and exfoliant microbeads), secondary microplastics degrade over time from larger plastics (e.g. fragments, films or fibers). Continental microplastics reach the oceans through water streams, wind, direct plastic littering or wastewater discharge (Cózar et al., 2014). Ingestion of microplastic particles have been reported by many previous studies (Hernandez-Gonzalez et al., 2018; Provencher et al., 2018; Zhu et al., 2019). It is also possible for microplastics to transfer through the food chain (Guzzetti et al., 2018), resulting in a high risk of exposure to humans.

Although microplastic effects and distribution in the environments have been subject of extensive research, its implications to human health and food security are still to be investigated. The presence of microplastics in market shellfish has been reported around the globe (Cho et al., 2019; Li et al., 2015; Li et al., 2018; Rochman et al., 2015; Van Cauwenberghe y Janssen, 2014). Nevertheless, there is no available information regarding seafood contamination in Peru. Indeed, information regarding plastic pollution in Peru is scarce (De-la-Torre y Laura, 2019; Purca y Henostroza, 2017).

Under this context, the aims of the present study were to (1) determine if commercial scallops from fishery markets of Lima were contaminated with microplastics, and to (2) determine whether microplastics are more likely to adhere to the scallop muscle or gonads.

\section{Materials and methods}

\section{Sampling and preparation}

Popular Peruvian scallops Argopecten purpuratus specimens $(\mathrm{n}=16)$ were bought from fishery markets of Lima, Peru, in April, 2019. Scallops were delivered in plastic bags and taken to the laboratory in a cooler. After dissection using a scalpel, valve length and wet weight of the gonads and muscle were measured and recorded separately. Samples were then frozen at $-20{ }^{\circ} \mathrm{C}$ until further analysis.

\section{Digestion treatment \\ For the digestion of the soft tissues, Protocol 1 b (Dehaut et al., 2016) was followed with minor changes. In brief, a pool of two gonads and muscles were placed in $30 \mathrm{ml}$ screw cab test tubes and $10 \%(\mathrm{w} / \mathrm{v})$ potassium hydroxide $(\mathrm{KOH})$ was added. The tubes were sealed and shaken for a few seconds. They were then incubated overnight at $60^{\circ} \mathrm{C}$.}

\section{Microplastic separation and identification}

The supernatant solutions of the digested material in the tubes were vacuum filtrated through a $20 \mu \mathrm{m}$ pore glass fiber filter paper using a $5 \mathrm{~cm}$ in diameter Büchner funnel.

Filters were then observed using a microscope (Krüss MBL2000) under 4 and $10 \times$ magnification. To differentiate microplastics from glass fibers, description by Davidson y Dudas (2016) was followed. Microplastic content, color and type (fiber, microbead, fragment and film) were recorded. All confirmed microplastics were photographed.

\section{Quality control}

Latex gloves and natural cotton lab coats were worn at all times. Glass equipment was rinsed with distillated water and surfaces were wiped clean. Plastic materials were avoided completely. A distillated water blank and $10 \% \mathrm{KOH}$ blank were prepared, vacuum filtrated and analyzed for every sample batch.

\section{ATR-FTIR Analysis}

To identify the specific polymer type of the microplastics and discard false positives, 10 microplastics were selected at random and analyzed through Attenuated Total Reflectance Fourier Transform Infrared Spectroscopy (ATR-FTIR). Some samples were initially too small for the ATR-FTIR 
(Perkin Elmer Frontier ${ }^{\mathrm{TM}}$ ) to analyze them, thus different filters were selected.

\section{Statistical analysis}

Data was expressed in microplastics per individual (MP.ind ${ }^{-1}$ ) and microplastics per gram of wet weight (MP.g-1) \pm standard error of the mean (SEM). To determine the normality of the data, both KolmogorovSmirnov and Shapiro-Wilk tests were conducted, invalidating its normal distribution $(P<0.05)$. To determine whether microplastics rather adhere to the gonads or the muscle tissues, nonparametric Mann Whitney $U$ test was conducted. Significance level was set to $95 \%$ for all the analyzes. Statistical analyzes and graphs were performed using GraphPad Prism (version 7.00 for windows).

\section{Results and discussion}

A. purpuratus biometrics (valve length and wet weight of the gonads and muscle) were presented in Table 1. Quality control measures prevented external contamination of the treatment, no microplastics were found in any of the blanks.

Microplastics were found in $87.5 \%$ of the pooled samples. The overall mean microplastic concentrations were $2.25 \pm$ 0.54 MP.ind $^{-1}$ and $0.13 \pm 0.03$ MP.g- $^{-1}$.

Table 1. Biometrics of the sampled scallops. Length was expressed in $\mathrm{cm}$ and mass in grams. $\mathrm{VML}=$ Valve mean length; GMW = Gonad mean weight; $\mathrm{MMW}=$ Muscle mean weight; and $\mathrm{TM}=$ Total mass

\begin{tabular}{lllll}
\hline & VML & GMW & MMW & TM \\
\hline MEAN & 7.74 & 5.34 & 12.36 & 17.71 \\
SEM & 0.06 & 0.37 & 0.46 & 0.72 \\
SD & 0.23 & 1.49 & 1.84 & 2.89 \\
\hline
\end{tabular}

Fibers (Figure 1) were the most abundant microplastic type (61.11\%), followed by fragments $(33.33 \%)$ and microbeads (5.56\%). No films were found.

Regarding color, red particles amounted $36.11 \%$ of the total microplastics, followed by blue $(27.78 \%)$, green $(19.44 \%)$ and black (16.67\%) microplastics.

Mann Whitney $U$ test indicated no significant difference $(P=0.1810)$ of microplastic content between gonads and muscle in terms of microplastics per individual. In terms of microplastics per grams of wet weight, no significant difference $(P=0.6444)$ was observed. These results evidence that microplastics adhere to the surface indistinctively on the soft tissues surface of A. purpuratus (Figure 2).

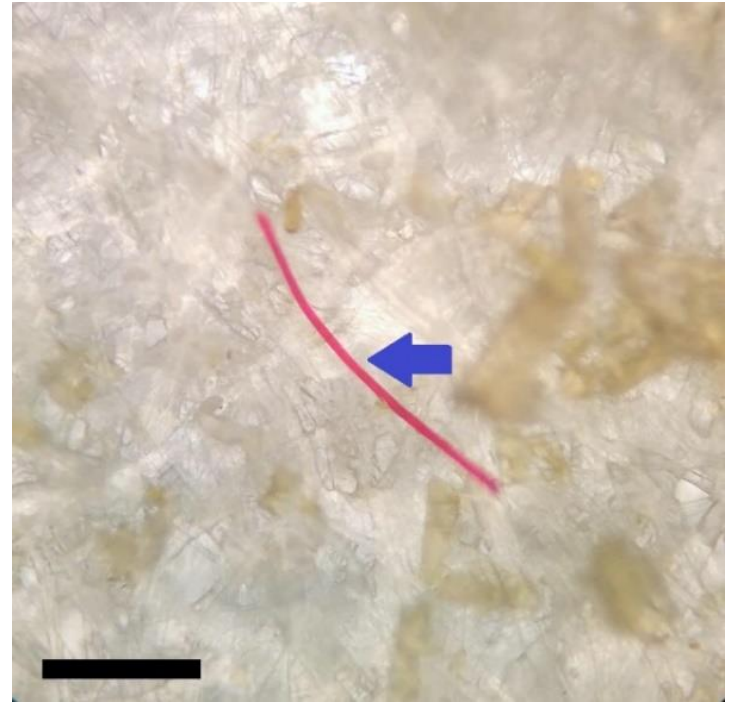

Figure 1. Photograph of a red fiber in a scallop from a fishery market. Scale bar indicate $100 \mu \mathrm{m}$.

ATR-FTIR spectra determined the polymer type of the selected microplastics. Most fibers were identified as polyester and polypropylene, fragments were identified as high-density polyethylene, polystyrene and isotactic polypropylene.

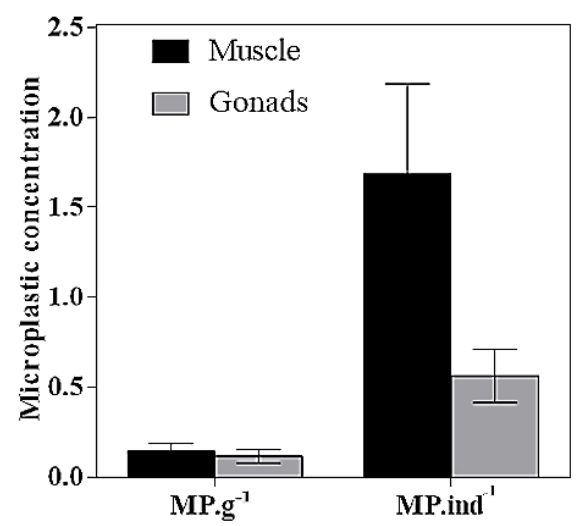

Figure 2. Column graph showing microplastic content between muscle and gonads in MP.ind ${ }^{-1}$ and MP.g- ${ }^{-1}$. Error bars indicate SEM. 
Supermarket live mussels (Mytilus edulis) from the UK contained $0.9{\mathrm{MP} . \mathrm{g}^{-1}}^{-}$(Li et al., 2018), considerably higher concentrations than those found in the present study. On the contrary, scallops and oysters from South Korean fishery markets, presented

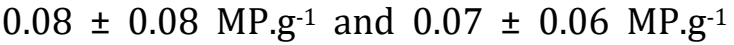
respectively (Cho et al., 2019). Fibers are among the most abundant microplastic types in mollusks from various studies (Catarino et al., 2018; Li et al., 2015; Li et al., 2018; Naji et al., 2018). Color could be of significant importance to organisms with selective feeding behavior.

Nevertheless, bivalves are known to be filter feeders, thus microplastic color may be correlated to those in the medium. Recent review articles (Barboza et al., 2018;
Rainieri y Barranco, 2019) have presented microplastic contamination as a threat to food security, food safety and human health. Whether microplastics could significantly damage human health is still under debate and requires more research.

The results of the present study indicated ubiquitous but small concentrations of microplastics adhered to the surfaces of $A$. purpuratus from fisheries of Lima.

Determining the precise source of microplastic pollution requires extensive monitoring and research with quality standards. In the case of seafood and food stuff contaminated with microplastics, it is likely to come from marine pollution and lack of hygiene standards along the supply chain.

\section{Conclusions}

In the present study, microplastic contamination of scallop A. purpuratus from fishery markets of Lima was assessed. Microplastic physical and chemical characteristics were presented. Results indicate that microplastic content on different parts of $A$. purpuratus are significantly equal. The present study evidenced a high risk of microplastic ingestion by locals. There is still scarce information regarding whether microplastics could pose a serious threat to human health through ingestion. Further research should focus on monitoring microplastics along the supply chain and elimination methods.

\section{Aknowledgements}

The authors would like to thank Prof. Sandra Casimiro, Head of Research and Teaching Laboratories, for allowing the research to be conducted in the research laboratories of San Ignacio de Loyola Uni- versity and providing the authors with high grade reagents and proper instruments.

This research was conducted by members of the Red Universitaria Ambiental (RUA) nodo USIL.

\section{References}

Andrady, A.L. 2017. The plastic in microplastics: A review. Marine Pollution Bulletin 119(1): 12-22.

Barboza, L.G.A.; Vathaak, A.D.; Lavorante, B.R.B.O.; Lundebye, A.; Guilhermino, L. 2018. Marine microplastic debris: An emerging issue for food security, food safety and human health. Marine Pollution Bulletin 133: 336-348.

Catarino, A.I.; Macchia, V.; Sanderson, W.G.; Thompson, R.C.; Henry, T.B. 2018. Low levels of microplastics (MP) in wild mussels indicate that MP ingestion by humans is minimal compared to exposure via household fibres fallout during a meal. Environmental Pollution 237: 675-684.

Cho, Y.; Shim, W.J.; Jang, M.; Han, G.M.; Hong, S.H. 2019. Abundance and characteristics of microplastics in market bivalves from South Korea. Environmental Pollution 245: 11071116.

Cózar, A.; Echevarría, F.; González-Gordillo, J.I.; Irigoien, X.; Úbeda, B.; Hernández-León, S.; Palma, A.T.; Navarro, S.; García-de-Lomas, J.; Ruiz, A.; Fernández-de-Puelles, M.L.; Duarte, C.M. 2014. Plastic debris in the open ocean. 
Proceedings of the National Academy of Sciences of the United States of America 111(28): 10239-10244.

Davidson, K.; Dudas, S.E. 2016. Microplastic Ingestion by Wild and Cultured Manila Clams (Venerupis philippinarum) from Baynes Sound, British Columbia. Archives of Environmental Contamination and Toxicology 71(2): 147-156.

Dehaut, A.; Cassone, A.L.; Frère, L.; Hermabessiere, L.; Himber, C.; Rinnert, E.; Rivière, G.; Lambert, C.; Soudant, P.; Huvet, A.; Duflos, G.; Paul-Pont, I. 2016. Microplastics in seafood: Benchmark protocol for their extraction and characterization. Environmental Pollution 215: 223-233.

De-la-Torre, G.E.; Laura, R.P. 2019. Composición, características físicas y generación per cápita de los residuos sólidos en la playa Las Sombrillas, Lima. Manglar 16(1): 39-44.

Guzzetti, E.; Sureda, A.; Tejada, S.; Faggio, C. 2018. Microplastic in marine organism: Environmental and toxicological effects. Environmental Toxicology and Pharmacology 64: 164-171.

Hernandez-Gonzalez, A.; Saavedra, C.; Gago, J.; Covelo, P.; Santos, M.B.; Pierce, G.J. 2018. Microplastics in the stomach contents of common dolphin (Delphinus delphis) stranded on the Galician coasts (NW Spain, 2005-2010). Marine Pollution Bulletin 137: 526-532.

Li, J.; Green, C.; Reynolds, A.; Shi, H.; Rotchell, J.M. 2018. Microplastics in mussels sampled from coastal waters and supermarkets in the United Kingdom. Environmental Pollution 241: 35-44.
Li, J.; Yang, D.; Li, L.; Jabeen, K.; Shi, H. 2015. Microplastics in commercial bivalves from China. Environmental Pollution 207: 190195.

Naji, A.; Nuri, M.; Vethaak, A.D. 2018. Microplastics contamination in molluscs from the northern part of the Persian Gulf. Environmental Pollution 235: 113-120.

Provencher, J.F.; Borrelle, S.B.; Bond, A.L.; Lavers, J.L.; van Franeker, J.A.; Kühn, S.; Hammer, S.; Avery-Gomm, S.; Mallory, M.L. 2019. Recommended best practices for plastic and litter ingestion studies in marine birds: Collection, processing, and reporting. FACETS 4: 111-130.

Purca, S.; Henostroza, A. 2017. Presencia de microplásticos em cuatro playas arenosas de Perú. Revista Peruana de Biología 24(1): 101-106.

Rainieri, S.; Barranco, A. 2019. Microplastics, a food safety issue? Trends in Food Science y Technology 84: 55-57.

Rochman, C.M.; Tahir, A.; Williams, S.L.; Baxa, D.V.; Lam, R.; Miller, J.T.; Teh, F.; Werorilangi, S.; Teh, S.J. 2015. Anthropogenic debris in seafood: Plastic debris and fibers from textiles in fish and bivalves sold for human consumption. Scientific Reports 5: 14340.

Van Cauwenberghe, L.; Janssen, C.R. 2014. Microplastics in bivalves cultured for human consumption. Environmental Pollution 193: 65-70.

Zhu, J.; Yu, X.; Zhang, Q.; Li, Y.; Tan, S.; Li, D.; Yang, Z.; Wang, J. 2019. Cetaceans and microplastics: First report of microplastic ingestion by a coastal delphinid, Sousa chinensis. Science of The Total Environment 659: 649-654. 